Ewa Sztymelska

Uniwersytet Warszawski

\title{
OBRAZ ŚWIATA W GEOGRAFII POWSZECHNEJ CZASÓW TERAŹNIEJSZYCH KAROLA WYRWICZA
}

SŁOWA KLUCZOWE: Karol Wyrwicz, Geografia powszechna czasów teraźniejszych, podręcznik do geografii, oświecenie, historia nauk geograficznych, nauka polska

Osiemnastowieczna geografia ściśle wiązała się z polityką, gospodarką i życiem społecznym. Jak pisał A. F. Büsching — niemiecki geograf z 2. poł. XVIII w.:

opis Ziemi jest potrzebny nauczycielowi i słudze bożemu, pożyteczny jest dla celów przyrodnika. Duże korzyści z niego ma podróżnik, a wszystkim służy jako pożyteczna rozrywka. Każdy wynosi korzyść ze znajomości geografii przy czytaniu gazet książek, a przy tym ma przyjemność z tego, że zna świat, na którym żyje.

[za: Augustowska, 1967, s. 119]

W Polsce wzrost zainteresowania geografią nastąpił w latach 20. XVIII w. W zreformowanych szkołach — najpierw teatynów, później pijarów (gruntowna reforma w latach 40. przeprowadzona za sprawą Konarskiego), a następnie jezuitów — geografia uzyskała status przedmiotu równorzędnego z innymi [Decyk-Zięba, 2009, s. 81].

Właśnie z myślą o szkole — kształceniu i wychowaniu młodzieży — Karol Wyrwicz, rektor warszawskiego Collegium Nobilium jezuitów, który znacząco przyczynił się do rozkwitu tej placówki i włączył ją w nurt reform prowadzonym przez obóz króla Stanisława Augusta Poniatowskiego, napisał podręcznik Geografia czasów teraźniejszych. Dzieło zostało wydane w Warszawie w 1768 r. Ukazało się w okresie represji politycznych ambasadora Rosji Repnina, który objął je indeksem. Jak podaje K. Augustowska, jezuici musieli podobno wycofać egzemplarze będące w druku, a już sprzedane — wykupywano i niszczono [1967, s. 126] ${ }^{1}$.

Po licznych modyfikacjach i uszczupleniach tekstu zmieniony podręcznik ukazał się w 1773 r. Jego pełny tytuł brzmi: Geografia powszechna czasów teraźniejszych albo opisanie krótkie krajów całego świata, ich położenia, granic, płodu ziemnego, skłonności obywatelów, handlu, obyczajów \&c. \&c. Z najświeższych

${ }^{1}$ Los ten spotkał książkę za zamieszczenie w niej ujemnej opinii o władzach Rosji [Augustowska, 1967, s. 126]. 
wiadomości Krajopisarzów i Wędrowników zebrana ku pożytkowi Młodzi Narodowej na szkoty publiczne wydana.

Gegrafia powszechna, kilkakrotnie wydawana za życia autora, wznowiona została w rocznicę jego śmierci w 1794 r. Z podręcznika korzystano w szkołach Komisji Edukacji Narodowej, a po upadku politycznym kraju był on podstawą i wzorem w literaturze pedagogicznej jeszcze w XIX w. [Tamże, s. 130-131].

Wyrwicz chciał dać kurs wiedzy, który by nie obciążał zbytecznie pamięci uczniów, a jednocześnie dawał młodzieży szlacheckiej wiadomości potrzebne jej w przyszłości [Lipko, 1966, s. 25]. W przedmowie do dzieła autor wyraźnie określa cel, jaki sobie wyznaczył:

Między naukami początkowemi, które młódź zdobią, do gruntowniejszych umiejętności układają, służą i zachęcają słusznie zabiera przodkowanie Geografia (...). Dlatego w powszechny zwyczaj to weszło, zaczynać młodzi płci obojej naukę od Geografii, aby łatwych i przyjemnych opisów przynętą, nieznacznie do trudniejszych ją pociągać, bez najmniejszego zrażenia ochoty, można było.

[Wyrwicz, 1773, s. IX-X]²

Opisany przez jezuitę świat ujęty jest w wielu wymiarach. W pierwszej części autor podejmuje kwestie teoretyczne: co to jest geografia (Geografia albo nauka krajopisarska, to jest tej części świata z lądu i wody złożonej, na której ludzie mieszkają (s. 1)), na jakie części się dzieli (względem czasu: dawna, średnia, teraźniejsza; względem rzeczy: naturalna, fizyczna, historyczna, kościelna, święta ${ }^{3}$; względem części ziemi: powszechna, chorografia albo geografia szczególna ${ }^{4}$, topografia, hydrografia; względem zwiazków ziemi z niebem i ludźmi: astronomiczna i polityczna). Następnie przechodzi do opisu poszczególnych państw.

Wyrwicz krytykował obcych autorów m.in. za zły rozkład materiału nauczania w podręcznikach, za rozwlekłość stylu, nieprzystępność treści i nieprzystosowanie jej do poziomu umysłowego młodzieży [Lipko, 1966, s. 25]. Przyjął jednak schemat opisu państw ustalony przez A. F. Büschinga:

1. Położenie geograficzne, terytorium, góry, niziny, rzeki, jeziora, bagna, lasy, krajobrazy itp.; 2. Nazwa kraju i jej pochodzenie; 3. Podział polityczny i administracyjny kraju; 4. Liczba ludności i jej zajęcia; 5. Fabryki, manufaktury, rzemiosła, handel; 6. Urodzajność ziemi i jej płody, kopaliny; 7. Dochody monarchów i kraju; 8. Siły zbrojne; 9. Ustrój państwowy; 10. Sztuki piękne, nauki, akademie; 11. Ciekawe osobliwości kraju: budowle, fortece, mosty, dziwy natury (dawne portenta); 12. Czasem religie, podział kościelny kraju, podział sądowniczy itp.

[Tamże, s. 25]

${ }^{2}$ Dalej przy cytatach z dzieła K. Wyrwicza numery stron podaję w nawiasie okrągłym.

3 Geografia święta opisuje kraje w piśmie świętym wzmiankowane (s. 1).

${ }^{4}$ Geografia szczególna albo chorografia przestaje na opisaniu szczególnego państwa, na przykład Polski, Litwy (s. 1). 
Wyrwicz wszystkie narody świata dzieli na: polerowane, grube, dzikie, błąkające się, rozproszone i ludożerców.

Wszystkienarody żyjące pod rządem politycznym, obyczajne, zprzepisu prawai wychowania prowadzące sposób życia przystojny, w naukach i kunsztach wyćwiczone, są polerowne. (...) Narody grube żyją bez ustanowionego kształtu rządów politycznych, chociaż mają niejaką obyczajność i niedoskonałą niektórych pożytecznych kunsztów wiadomość (...). Narody dzikie w grubej nauk i kunsztów, oraz prawego rządu niewiadomości zostają, i obyczajów żadnym prawem nie mają przepisanych (...) Narodami błąkającemi się albo Nomades nazywają się ci ludzie, którzy ani domów, ani osiadłości stałych nie mają, lecz z jednego na drugie przenoszą się miejsce, pod namiotami, albo w chałupach pastuszych na polu i między taborami mieszkają. (...) Narody rozproszone są, które niemając kraju żadnego w szczególności sobie właściwego między obcemi tułają się narodami (...) Ludojedzcy Antropophagi ludzkim karmią się mięsem.

(s. 55-56).

Charakterystyczna w opisie jest wyraźna antynomia europejski — nieeuropejski. To w Europie żyją narody polerowane, czyli ucywilizowane ${ }^{5}$, te, które przez prawa i obyczaje (...) różnia się od grubych, dzikich, błakajacych się, rozproszonych i ludojedzców (s. 55). Pisarz dodawał, że są jednak jeszcze w Europie narody, które nie otarly ze wszystkim swej grubości, ani wyrogowały z postępków okrucieństwa, które wszystkich grubych narodów jest cecha $i$ znamieniem ${ }^{6}$. To, co nieuropejskie jest zatem barbarzyńskie, nieokrzesane - grube $^{7}$. Podstawową antynomią jest tu opozycja znane - obce. Nieznane odbieranie jest z jednej strony jako gorsze wobec najznakomitszej części świata, czyli Europy, z drugiej — jako nieprzyjazne człowiekowi, czyli Europejczykowi [Zob. Decyk-Zięba, 2009, s. 243-244]. Dlatego właśnie o rdzennych mieszkańcach Nowego Świata jezuita pisał:

Amerykanie rodowici brakiem zdają się być rodzaju ludzkiego albo ludźmi od natury jeszcze niedokończonymi i w przymiotach tak ciała jako duszy upośledzonymi, dla tego pierwsi nasi do nieznajonego świata zawodzcy wzięli ich niezdrożnie za matpy ludźmi leśnymi nazwane.

Trzeba jednak podkreślić, że autor podręcznika opisu nie opiera na podziale dobry - zły. Uważał on, że jak każdy człowiek ma charakterystyczne dla siebie cechy, tak charakter każdego narodu stanowią własności przyrodzone złe lub dobre (s. 56). Europocentryzm Wyrwicza nie był bezkrytyczny, chociaż przyznaje on, że:

5 Polerowany 'ucywilizowany, utartych obyczajów, okrzesany, ociosany' - Stownikjęzyka polskiego, B.S. Linde (red.), [oline] [dostęp 20.08.2012] http://kpbc.umk.pl/dlibra/publication?id=8173\&tab=3 .

${ }^{6}$ Wyjąwszy Tatarów i Lapończyków wszystkie w Europie narody sa polerowne, albo polityczne, jedne jednak obyczajniejsze i grzeczniejsze od drugich. Te które niedawnemi czasy polerować się zaczęly, niotarty ze wszystkim swej grubości, ani wyrogowały z postępków okrucieństwa, które wszystkich grubych narodów jest cechą i znamieniem (s. 57).

7 Gruby: 'prymitywny, niedoskonały, nieukształtowany, prostacki, pospolity, barbarzyński, nieokrzesany', Stownik polszczyzny XVI wieku, [online], serwis Kujawsko-Pomorskiej Biblioteki Cyfrowej [dostęp 25.08.2012] http://kpbc.umk.pl/publication/17781. 
O Europejskich narodach można mówić, że wich charakterze więcej dobrych, niż ztych wydaje się sktonności (s. 56).

Wyraziste jest natomiast modelowanie opisu przez stereotyp. Wyrwicz wychodzi z założenia, że pewne cechy właściwe narodom są niezmienne i pewne. Argumentuje: W przysłowie poszło mówić, lekki jak Francuz, figlarny jak Włoch, poważny jak Hiszpan, złośliwy jak Anglik, dumny jak Szkot, gnuśny jak Irlandczyk, pijak jak Niemiec, chytry jak Greczyn \&c (s. 55). Odwołuje się do tradycji społecznej. O ocenie decyduje doświadczenie i utarte wyobrażenia, a nie logiczne myślenie. Rzeczywistość nie jest przedstawiana obiektywnie, lecz uczuciowo.

Jak podkreśla Kazimierz Puchowski, popularne w tamtych czasach katalogi cnót i wad służyły jako przewodniki w naukowych czy dyplomatycznych peregrynacjach, a także handlowych i kupieckich przedsięwzięciach. Wymienienie cech poszczególnych narodów stanowiło lekcję nauki moralnej i obywatelskiej [Puchowski, 2005, s. 239-239]. Część dotycząca „przymiotów i charakretu” pojawia się przy opisie każdego państwa w podręczniku Wyrwicza. Autor konsekwentnie podaje zarówno wady, jak i zalety mieszkańców. Na przykład u mieszkańców Państwa Kościelnego i wszystkich Włochów Wyrwicz ceni: roztropność, dowcip, wstrzemięźliwość. Zaznacza jednak, że słuszna pada na Włochów nagana, że sa mściwi, skryci, zdrajcy, zawiśni, podejrzenia petni, w okazałościach powierzchnownych zatopieni (s. 62).

Surowo ocenia Neapolitańczyków. Uważa, że są: niestateczni, próżnujący, skryci i szalbierze, a jako potwierdzenie swoich słów przytacza przysłowie: Neapol jest rajem zamieszkanym przez diabłów (s. 65). Oddaje jednak im sprawiedliwość i zaznacza, że są również hojni oraz ludzcy wobec tych, którzy wiedzą, jak z nimi postępować.

Niekiedy autor stara się łagodzić negatywną ocenę i unika nazywania pewnych przywar wprost. O Niemcach pisze: nie sa zbytnia rozumu ostrościa zaszczyceni, zdatni jednak do handlu i kunsztów (s. 85). O Szwedach: Własność powietrza zimnego ale zdrowego daja Szwedom postanowienie ciała mocne, rozum zaś czynia mniej bystrym i przenikajacym (s. 188). W przytoczonym fragmencie warto również zwrócić uwagę, że typowe cechy Szwedów Wyrwicz łączy z wpływem klimatu. Takie rozumowanie jest zgodne z poglądami Monteskiusza, który uważał, że klimat ma wpływ na postawy ludzkie, hierarchie wartości.

Wyrwicz akcentuje również cechy fizyczne. Dokładnie opisuje kolor cery poszczególnych nacji (biała, czarna, czarniawa, czarnooliwkowata, oliwkowata, żółta, żółtawa, ogorzała, miedziana, śniada), a także proporcje i budowę ciała, Narody, których obywatele są ,,przystojnej postaci”, ,wysocy”, ,wzrostu pięknego”, zyskują uznanie jezuity.

Najczęściej pojawiającą się zaletą jest dowcip, czyli w dawnym znaczeniu 'rozum, inteligencja, bystrość umysłu, przemyślność, spryt'. Natomiast szczególnie piętnowane jest pijaństwo. Jezuita ubolewa, że cudzoziemscy pisarze zarzucają Polakom skłonność do hulaszczego życia. Uważa jednak, że jest to przywara charakterystyczna dla wielu narodów. Tak pisał na przykład o Irlandczykach, Anglikach 
i Szkotach: Jedna wada wszystkie te trzy narody zbliża, to jest pijaństwo, którym jednak Irlandczyk Szkota, a Szkot przenosi Anglika, wszyscy zaś trzeh swych sasiadów (s. 174-175).

Postawę autora podręcznika cechuje widzenie świata w wymiarze konfesjonalnym. W jego świecie panuje porządek religijny wynaczony przez przykazania. Negatywnie oceniane są więc narody, których obywatele nie żyją w zgodzie zasadami i wartościami chrześcijańskimi. Na naganę zasługują: lenistwo, próżność, pycha, nieumiarkowanie w jedzeniu i piciu, bycie pysznym, wiara w zabobony, świętokradztwo, poddawanie się rozkoszom i rozpuście.

Jednoznacznie negatywnie oceniani są Żydzi. Pojawia się stereotyp Żyda lichwiarza, skąpca. Geograf zauważa, np. że: Ostrość rozumu i dowcip przenikajacy sa Portugalczykom udzielone od przyrodzenia, a lakomstwo i żadza zebrania lichwiarstwem bogactw od powinowactwa z Żydami (s. 159).

Równie ważna jest dla jezuity postawa obywatelska wobec państwa. Do cnót obywatelskich Wyrwicz zalicza: pracowitość, roztropność, wstrzemięźliwość, sposobność do wszystkich nauk i kunsztów, bystrość, wierność, trwałość w przedsięwzięciach. Docenia narody odważne i umiejące znosić trudy wojny. Wiele uwagi poświęca również stosunkowi do cudzoziemców. Ceni gościnnośc, otwartość, przyjazność i — jak to określa — „ludzkość”.

Można chyba powiedzieć, że uwagi Wyrwicza o wadach i zaletach innych nacji wynikały z pragnień, by jego wychowankowie sprostali kryteriom, które wyróżniają najświatlejszych mieszkańców Europy [Puchowski, 2005, s. 242]. Autor podręcznika nie jest zatem bezkrytyczny również wobec rodaków. Pisał: Polacy, jak wszystkie inne narody, z dobremi i złemi rodza się i żyja przymiotami; $w$ tym szczęśliwi, że wady ich nie góruja nad skłonnościami chwalebnymi i prawym moga być wytępione wychowaniem (s. 386).

Warto zwrócić uwagę, że w szkołach polskich XVIII wieku geografia była „drugim okiem" historii — miała służebny charakter w stosunku do innych przedmiotów szkolnych [Lipko, 1966, s. 3]. Jak zauważa S. Lipko:

geografia, zwłaszcza polityczna, stała się narzędziem walki ideologicznej między zwolennikami reformy politycznej a reprezentantami magnacko-szlacheckiej anarchii (...). Stawała się ona orędownikiem oświaty opartej na filozofii recentiorum (...). Używano jej wreszcie jako środka szerzenia nowych systemów moralnych,

Wyrwicz był przeciwnikiem systemu szkolnictwa, który doprowadzał do tego, że młodzi szlachcice osiemnastu lat dopetniwszy, do wolności wzdycha, a wyszedtszy z akademii, tego, czego się nauczyła, $w$ domu ojcowskim zapomina, abo przynajmniej na pierwiastkowym przestając polorze do urzędów, a zwłaszcza poselstwa na sejm się drze i natrętnie ubiega (s. 387). Jako zwolennik króla i silnej władzy monarchii negatywnie oceniał wzrost przywilejów szlachty rodzący prywatę, postępującą anarchizację, przekładanie korzyści własnych nad dobro państwowe, skłonność do zbytku i wygody. Krytycznie ocenia liberum veto: Za Jana Kazi- 
mierza dopuszczona jednego poselskiego głosu powaga, jakie sprawiła i sprawuje skutki, każdy bacznie widzi i utyskuje obywatel (s. 666).

Jednocześnie jezuita wysoko ceni wolność osobistą, odrzuca poddańczą postawę wobec władzy, jej despotyzm. Przedstawia negatywny obraz narodu moskiewskiego i Moskali, którzy Żyjąc w niewoli pod panami także niewolnikami, nie znali ani nauk i kunsztów, ani poznawali swych słasnych potrzeb i pożytków (...). Za Piotra $W$, prawodawcy tego narodu, zaczęli trochę się polerować $i$ z cudzoziemskimi krajami poznawać (...). Jednakże umyst ich ma coś jeszcze niewolniczego i braknie im na tych pobudkach sławy i honoru, które czynia ludźmi wielkimi (s. 133-134).

Podręcznik Karola Wyrwicza przybliżał ówczesnym czytelnikom obcy świat. Pokazywał zarówno zjawiska znane, jak i nieznane, które autor odnosił do realiów polskich. Jezuita - jako propogator postępu, reformy - chciał wpoić swoim uczniom wartości oświecenia. Podręcznik był znany w niewielkim kręgu (w prowincjonalnych szkółkach jezuickich i niejezuickich geografii najczęściej nie wykładano), dlatego — jak służnie zauważa S. Lipko — pozwala jedynie wytworzyć obraz, czego powinny szkoły uczyć, ale nie daje sprawdzianu, czego naprawdę uczono [1966, s. 33]. Mimo to nie wolno pomijać wartości edukacyjnej dzieła i roli, jaką odegrało w trudnych dla Polaków czasach upadku kraju.

\section{Bibliografia}

Augustowska K., 1967, Karol Wyrwicz [w:] Dziewięć wieków geografii polskiej, Olszewicz B. (red.), Warszawa, s. 117-137.

DECYK-ZIĘBA W., 2009, „Lexykon geograficzny” bazylianina Hilariona Karpińskiego. Studium historycznojęzykowe (wybrane zagadnienia), Warszawa.

LIPKO S., 1966, Podręcznik geografii w szkołach polskich XVIII wieku, „Rozprawy z Dziejów Oświaty", t. IX, s. 3-33.

Puchowski K., 2005, Wizerunek rodaków w , Geografii powszechnej” Karola Wyrwicza [w:] Między zachodem a wschodem. Etniczne, kulturowe i religijne pogranicza Rzeczypospolitej w XVI-XVIII wieku, Mikulski K., Zielińska-Nowicka A. (red.), t. 3, Toruń, s. 238-244.

Wyrwicz K., 1770, Geografia powszechna czasów teraźniejszych albo opisanie krótkie krajów całego świata, ich położenia, granic, płodu ziemnego, skłonności obywatelów, handlu, obyczajów \&c. \&c. Znajświeższych wiadomości Krajopisarzów $i$ Wędrowników zebrana ku pożytkowi Młodzi Narodowej na szkoły publiczne wydana w Warszawie w Drukarni J.K.MCI i Rzeczypospolitej in Collegio Soc. Jesu, MDCCXX, Warszawa. 